\title{
Statyba
}

\section{PRACTICAL TECHNIQUES FOR DETERMINING OF AVERAGE STRESS-STRAIN RELATIONSHIPS FOR CONCRETE FROM EXPERIMENTAL DATA OF RC BENDING MEMBERS}

\section{G. Kaklauskas}

To cite this article: G. Kaklauskas (1998) PRACTICAL TECHNIQUES FOR DETERMINING OF AVERAGE STRESS-STRAIN RELATIONSHIPS FOR CONCRETE FROM EXPERIMENTAL DATA OF RC BENDING MEMBERS, Statyba, 4:1, 20-28, DOI: 10.1080/13921525.1998.10531375

To link to this article: https://doi.org/10.1080/13921525.1998.10531375

曲 Published online: 26 Jul 2012.

Submit your article to this journal $\widetilde{ }$

Џll Article views: 356

4 Citing articles: 1 View citing articles 준 


\section{PRACTICAL TECHNIQUES FOR DETERMINING OF AVERAGE STRESS-STRAIN RELATIONSHIPS FOR CONCRETE FROM EXPERIMENTAL DATA OF RC BENDING MEMBERS}

\section{G. Kaklauskas}

\section{Introduction}

In usual structural analysis problems, strength and strains (curvature) have to be defined when material properties are given. Unfortunately, assumed material stress-strain relationships often are too simplified, do not reflect a complex multi-factor nature of the material and therefore are inaccurate. Such an example is a material stress-strain relationship for concrete in tension shown in Fig 1. Due to bond with steel, tensile concrete in cracked reinforced concrete structures has properties different from those which are obtained from simple material tests. Similarly concrete stressstrain curves obtained from tension tests of reinforced concrete members do not necessarily assure accurate results for calculation of bending structures. Therefore, quite naturally a researcher is challenged to solve a problem of bending analysis in an opposite way: to derive concrete material stress-strain relationships for given experimental moment-strain (curvature) diagrams. Subsequently, on a basis of such relations a new stress-strain calculation model could be developed.

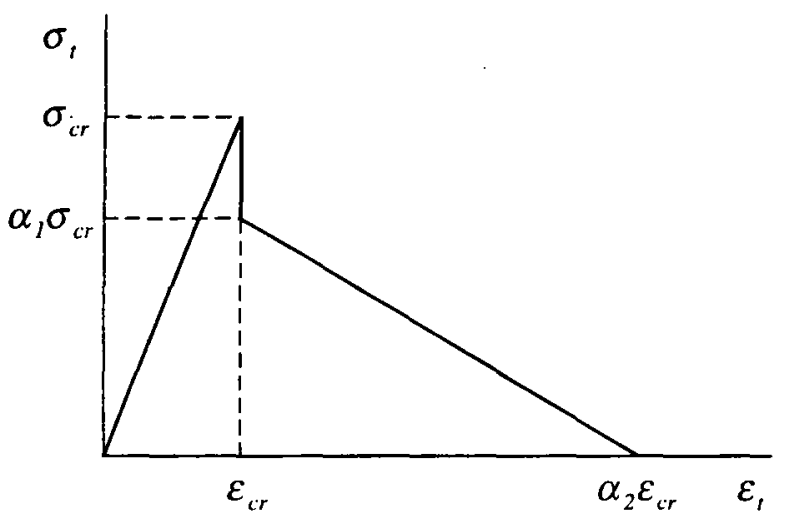

Fig 1. Average stress-strain relationship for concrete

Recently a new method has been proposed [1-5] for determining average concrete stress-strain relationships from experimental data of flexural reinforced concrete structures. In this paper, which actually is the extension of [1] firstly the formulation of the method and its numerical verification is given. Secondly, two practical techniques based on the method are proposed.

\section{Description of the method}

The present work is based on the following assumptions of behaviour of flexural reinforced concrete members: (1) The assumption of plane sections is adopted implying a linear distribution of strain within the depth of the beam section. Due to discrete cracking nature of reinforced concrete structures, this assumption appears to be not accurate when separate normal sections are considered. Cracked sections do not remain plain and also have larger strains than the sections between cracks. However, experimental investigations have shown that this assumption is accurate enough for everaged strains and stresses when averaging is performed for the length equal to the distance between two adjacent cracks; (2) Perfect bond between reinforcement and concrete is assumed. Reinforcement slippage occurring at advanced stress-strain states is included into $\sigma-\varepsilon$ diagram of tensile concrete; (3) The constitutive model is based on a smeared crack approach, ie average stresses and strains are used; (4) All fibres in the tensile concrete zone follow the same stress-strain law. Similarly, this is also applied to the fibres of the compressive zone.

The latter assumption is less accurate for tensile concrete since for the given constant strain in the cracked concrete, fibres close to the reinforcement carry larger average stresses than fibres more distant from that reinforcement.

Consider a non-prestressed doubly reinforced concrete member (Fig 2) subjected to bending only. Curvature can be determined from strains for two different fibres as

$$
\kappa=\frac{\varepsilon_{t}-\varepsilon_{c}}{h}=\frac{\varepsilon_{s}-\varepsilon_{c}}{d}
$$


where $\varepsilon_{c}, \varepsilon_{t}$ are average strains at extreme concrete fibres in compression and tension respectively; $\varepsilon_{s}$ is average tensile reinforcement strain; and $h$ and $d$ are the overall depth and effective depth of the crosssection, respectively.

The location of the neutral axis can be defined by

$$
y_{c}=\frac{\varepsilon_{c}}{\varepsilon_{l}-\varepsilon_{c}} h=\frac{\varepsilon_{c}}{\varepsilon_{s}-\varepsilon_{c}} d
$$

and from strain compatibility considerations, the strain at any fibre can be expressed as:

$$
\varepsilon_{x, i}=\kappa y_{i}
$$

where $y_{i}$ is the distance of the fibre from the zero strain surface. The sign convention adopted is that tension, extension, and distance below the neutral axis are positive.
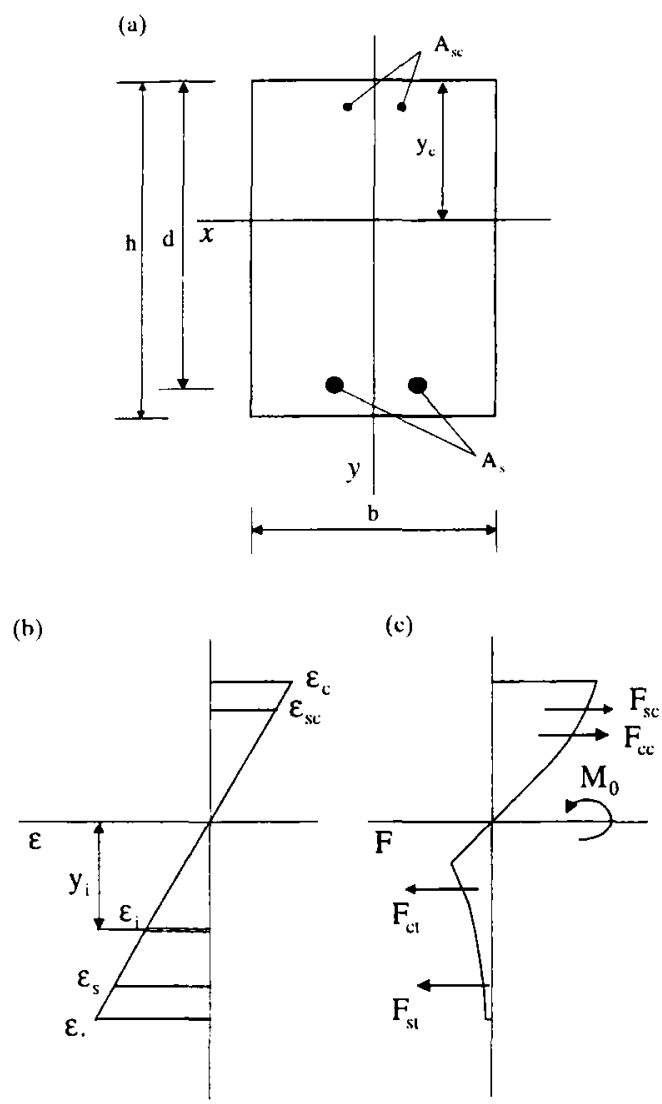

Fig 2. Reinforced concrete section subjected to bending moment. (a) - a doubly reinforced section; (b) - strain compatibility; (c) - internal forces and external bending moment

From equilibrium

$$
\begin{gathered}
F_{c c}+F_{s c}+F_{c t}+F_{s t}=0 \\
M_{c c}+M_{s c}+M_{c t}+M_{s t}-M_{0}=0
\end{gathered}
$$

where $F$ are internal forces, $M$ are internal moments with respect to the neutral axis, and $M_{0}$ is the external bending moment. The first subscript corresponds to either $\mathrm{c}$ for concrete or $\mathrm{s}$ for steel and the second subscript refers to compression (c) or tension ( $t$ ). The sign of the force $F$ is the same as for the corresponding strain $\varepsilon_{x, i}$

This work is aimed at determining average material stress-strain, $(\sigma-\varepsilon)$, curves for concrete directly from experimental data for reinforced concrete beams or one-way slabs subjected to bending moment. The experimental data used can be as follows: (a) momentaverage strain relation for extreme fibre of compressive concrete; (b) moment-average strain relation for extreme fibre of tensile concrete; (c) moment-average strain relation for tensile reinforcement; (d) momentcurvature relation; (e) reinforcement steel stress-strain relation.

Consider a case when relations (a), (b), and (e) are available. Then, the location of the neutral axis and average strains at any fibre for all loading stages can be determined from Eqs (1-3). Two equilibrium equations (4) and (5) can be solved for each loading stage yielding a solution for two unknowns. A layered model can be conveniently employed for computation of internal forces in the cross-section. Stresses and internal forces in the reinforcing bars can be determined from the longitudinal strains using reinforcement $\sigma-\varepsilon$ curves. Since the external moment $M_{0}$ is known, average stresses for the tensile and compressive concrete zones could be the two unknowns in the equilibrium equations (4) and (5). However, there are many fibres (layers) in both the tensile and compressive concrete zones and the variation in stresses in each of these zones is not known.

A simple concept, based on the assumption of constant stress-strain diagrams allows the reduction of the number of unknowns to one for each zone. The equilibrium equations are solved for concrete stresses at extreme fibres. Since the extreme fibres have the highest strains, all other fibres have lower strains, and therefore fall within the portion of the stress-strain diagram which has already been determined.

The proposed method is illustrated in Fig 3. It is assumed that the "experimental" moment-average strain curves for extreme fibres of the compressive and tensile concrete are given, as in Figs 3(a) and (b), res pectively. Circled points in these curves correspond to 
(a)

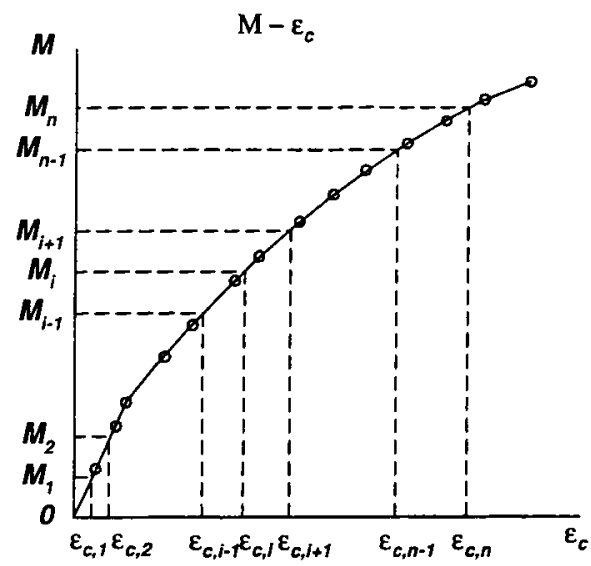

(c)

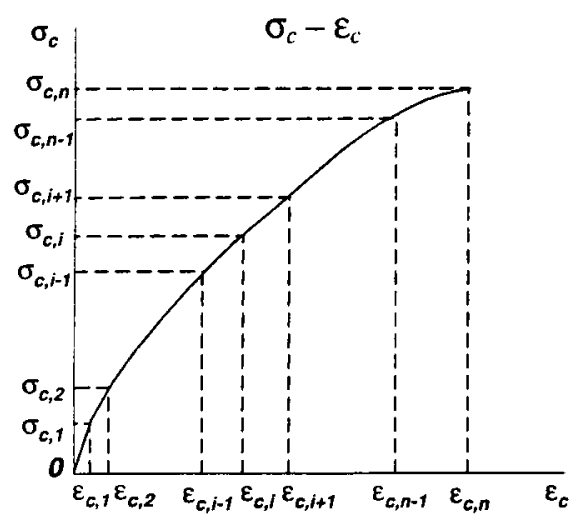

(b)

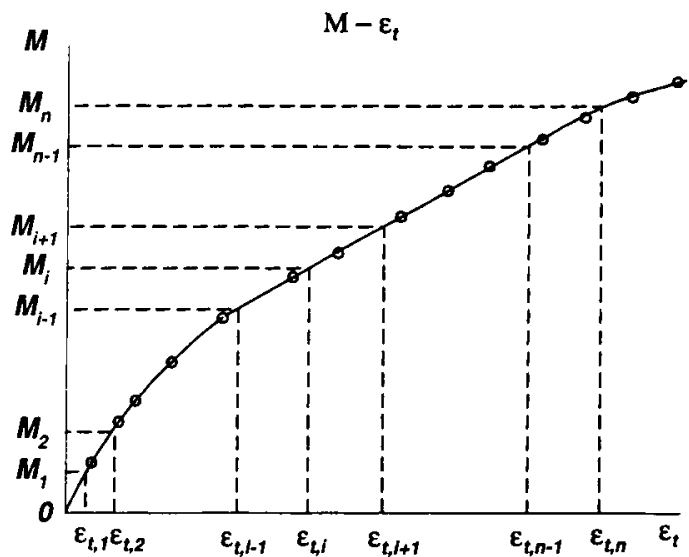

(d)

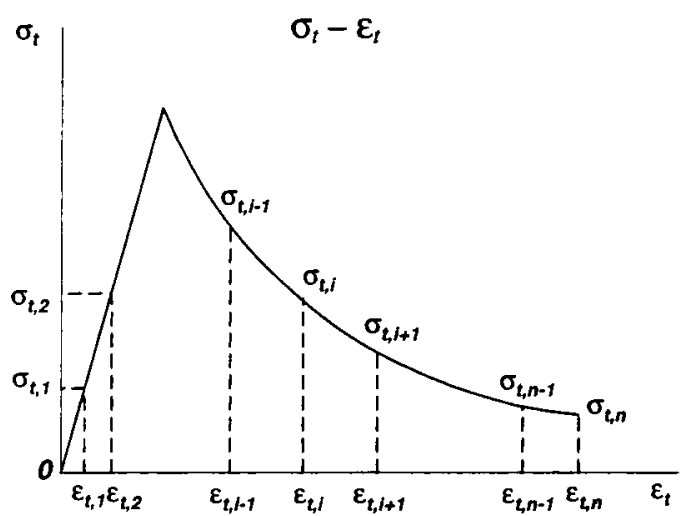

Fig 3. "Experimental" moment-strain curves and computed stress-strain relationships for concrete

experimental data. Simple linear connection of experimental points would give discontinuous momentstrain curves. MATLAB [6] is used in the present work to smooth the $M-\varepsilon$ curves. Computation is performed for incrementally increasing load. During the first load stage, tensile and compressive concrete stresses corresponding to the strains in the extreme fibres are computed. These stresses are then used in the equilibrium equations for the second load stage when new stresses corresponding to larger extreme fibre strains are determined. In this way, stress-strain curves for the tensile and compressive concrete (Figs 3(c) and (d)) are progressively obtained from all previous stages and used in the next load stage. More detailed illustration of the method is given in [1].

\section{Numerical verification}

The proposed method has been tested on a numerical example. The test procedure is described in the following. Consider a fully defined cross-section of a reinforced concrete member with assumed physical models for reinforcing steel and both compressive and tensile concrete. First, moment-strain relations have to be generated. Next, from these moment-strain relations, material stress-strain relations for both compressive and tensile concrete are computed by the proposed method. The test is considered successful when the initially assumed and computed material $\sigma-\varepsilon$ relations coincide.

The data from a physical experiment on a reinforced concrete beam [7] have been chosen for this validation test. The cross-section and physical-mechanical properties of the beam chosen for this validation test are shown in Fig 4 . The stress-strain relation presented in Fig 1 is assumed for the tensile concrete $\left(\alpha_{1}=1\right.$ and $\alpha_{2}=20$ ). The stress-strain relation for the compressive concrete is assumed to be as follows:

$$
\sigma_{c}=f_{c}^{\prime}\left[2 \frac{\varepsilon_{c}}{\varepsilon_{0}}-\left(\frac{\varepsilon_{c}}{\varepsilon_{0}}\right)^{2}\right]
$$


where

$$
\varepsilon_{0}=2 f_{c}^{\prime} / E_{c}
$$

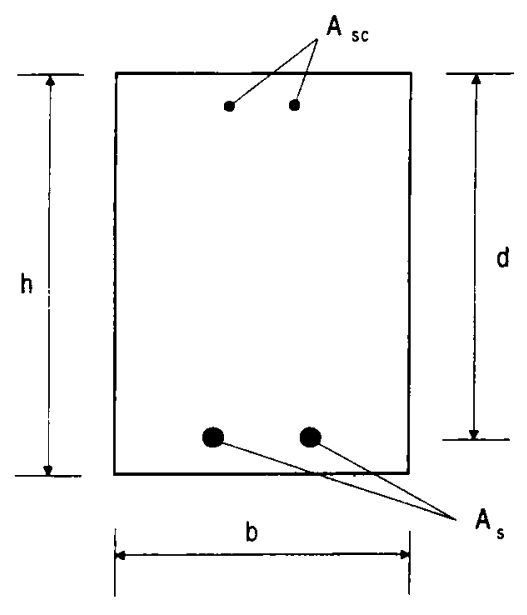

$h=0.18 \mathrm{~m} ; b=0.10 \mathrm{~m} ; d=0.16 \mathrm{~m}$

$A_{s}=1.51 \times 10^{-4} \mathrm{~m}^{2} ; A_{s c}=0.51 \times 10^{-4} \mathrm{~m}^{2}$;

$E_{c}=3.95 \times 10^{-4} \mathrm{MPa} ; f_{c}^{\prime}=41.25 \mathrm{MPa}$;

$\varepsilon_{0}=0.0021 ; f_{c r}=3.0 \mathrm{MPa}$;

$E_{x}=1.97 \times 10^{5} \mathrm{MPa} ; \quad f_{y}=420 \mathrm{MPa}$;

$p=0.94 \%$.

Fig 4. A cross-section and physical-mechanical characteristics of experimental reinforced concrete beam [7]

Here $\sigma_{c}$ and $\varepsilon_{c}$ are the stress and strain respectively of the compressive concrete; and $f_{c}^{\prime}$ and $\varepsilon_{0}$ are the maximum compressive stress and the corresponding strain for standard cylinder test. Though both values in computations are taken as negative, in the text the sign minus is omitted.

A special program was developed for stress-strain and curvature computation of a layered cross-section with non-linear material properties. Moment-strain diagrams $M-\varepsilon_{c}, M-\varepsilon_{t}$ and $M-\varepsilon_{s}$ for the extreme concrete fibres and tensile reinforcement respectively shown in Fig 5(a) and moment-curvature $(M-\kappa)$ diagram shown in Fig 5(b) were generated. From the $M-\varepsilon_{c}$ and $M-\varepsilon_{t}$ diagrams, stress-strain relations for tensile concrete $\left(\sigma_{t}-\varepsilon_{t}\right)$ and for compressive concrete $\left(\sigma_{c}-\varepsilon_{c}\right)$ were computed by the method described here. The corresponding relations are plotted along with the assumed relations in Fig 6. It can be seen that the agreement is good and, therefore, the proposed method can be used to establish reasonable stress-strain relations from beam or slab data. a)

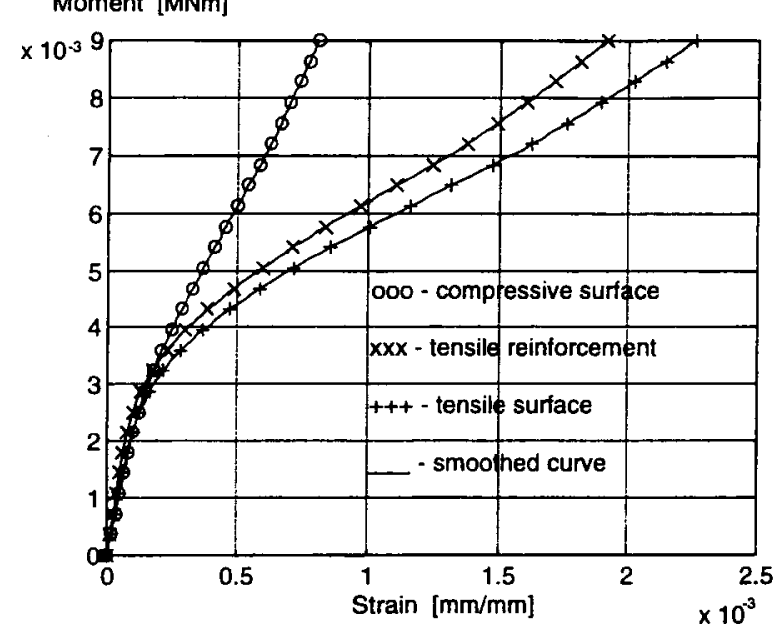

b)

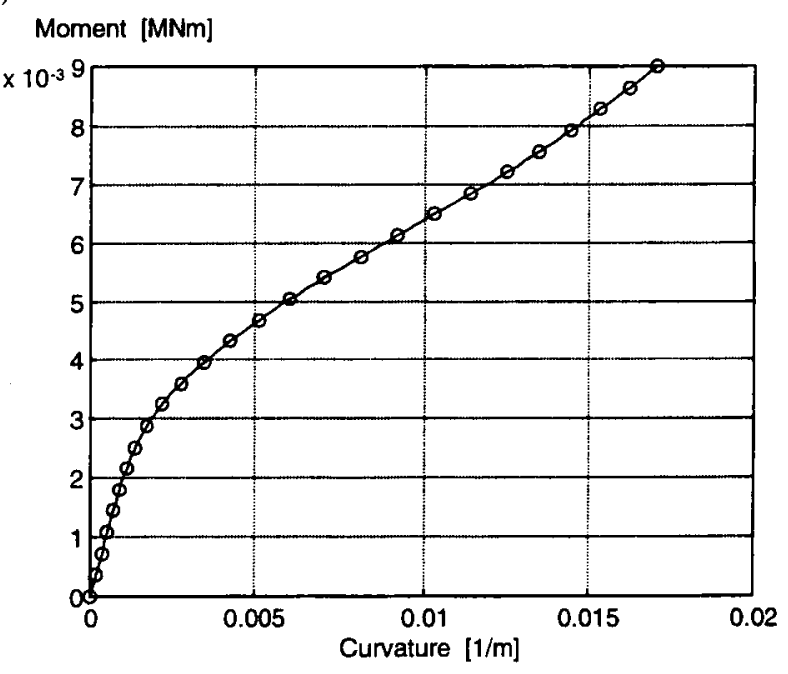

Fig 5. Assumed moment-strain (and curvature) relationships in the numerical test (a) - moment-strain curves (b) - moment-curvature curve

\section{Practical techniques for determination of stress- strain curves}

The numerical example presented above represents an ideal case, since the moment-strain diagrams were devoid of scatter. Experimental data, on the other hand, often contains a considerable amount of measurement scatter which may result in oscillatory and irregular results, particularly for compressive concrete. A variety of stress-strain diagrams for compressive concrete has been proposed by different authors [8-15]. The disagreement between diagrams and their corresponding influence on the computed deflections and strains of beams is not significant and usually far less significant than the disagreement due to variations in the tensile concrete models. Since stress-strain relations for 
a)

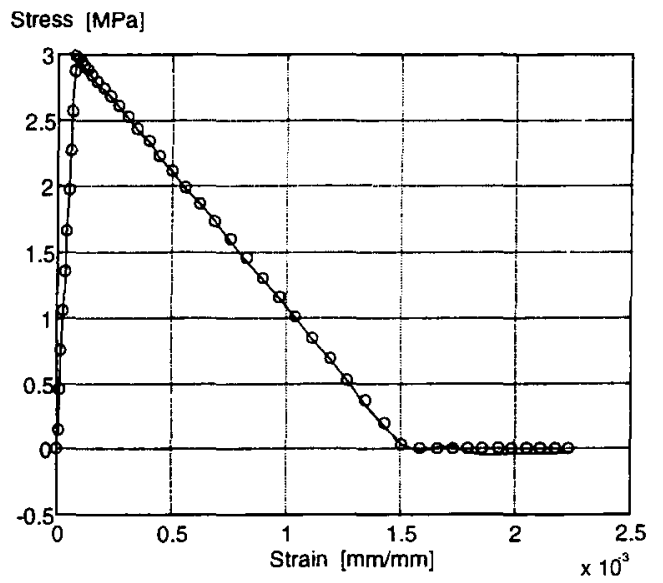

b)

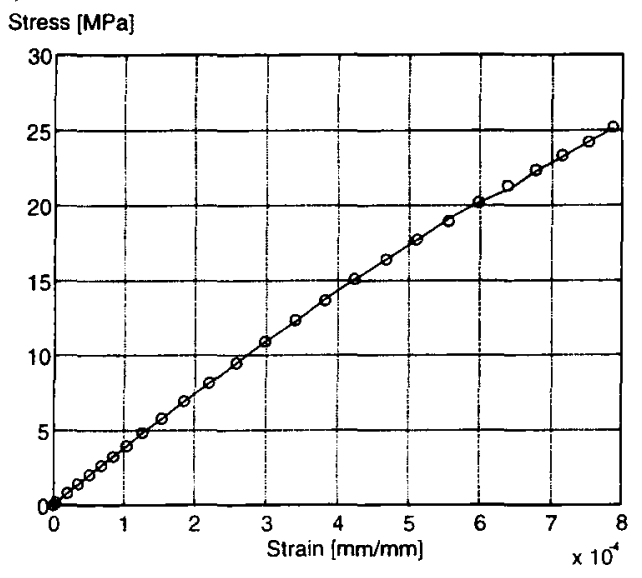

Fig 6. Comparison of initially assumed and computed concrete stress-strain relationships (a) - for tensile concrete; (b) - for compressive concrete

oooo - initially assumed —_ - computed

concrete in compression have been investigated extensively and are known to vary little with the properties of the cross-section, such as shape, reinforcement diameter, ratio, location, etc, reasonable $\sigma-\varepsilon$ diagram can be assumed for compressive concrete. That assumption is justified even more by the prime purpose for the present work which is to investigate tension stiffening effects, ie the form for the average $\sigma-\varepsilon$ curve for cracked tensile concrete and the effect that form has on curvatures. The simple expression $\mathrm{Eq}(6)$ often used by other researchers, is also applied in this work. Based on the proposed method, two techniques for practical computation of $\sigma-\varepsilon$ relations have been developed depending on whether the complete $\sigma_{c}-\varepsilon_{c}$ relation is assumed or just the shape.

1) A complete $\sigma_{c}-\varepsilon_{c}$ curve can be assumed from cylinder test results or by using cylinder test data $f_{c}^{\prime}, E_{c}$ and $\mathrm{Eq}(6)$. When a complete $\sigma_{c}-\varepsilon_{c}$ diag- ram is assumed, one experimental moment-average strain curve is sufficient for computing the $\sigma_{t}-\varepsilon_{t}$ diagram. It is expected that the most accurate results will be achieved when the moment-steel strain, and, particularly, moment-curvature diagrams are used. The latter can be obtained from two strains (Eq (1) and (2)) or from a deflection defined for the response of the beam in its region of pure bending.

The experimental relationship for one fibre strain, (or one curvature relationship) is not sufficient to define the strain distribution over the depth of the crosssection. One of the geometrical parameters has to be assumed as an unknown. It is convenient if this unknown is the height of the compressive zone $y_{c, i}$ since it has predefined limits. Unfortunately, an explicit solution cannot be obtained in that case and the solution has to be obtained by iterations. The following is a brief description of the sequence of computation. First, $y_{c, i}$ is assumed and then $\sigma_{t, i}$ is obtained explicitly from the equilibrium equation for horizontal forces. If internal and external moments are not equal within the specified error, the computation is repeated for the improved $y_{c, i}$ value.

The numerical test of the method described previously has been again applied and that test gave excellent agreement between the initially assumed and the computed $\sigma_{t}-\varepsilon_{t}$ diagram.

2) A shape for the $\sigma_{c}-\varepsilon_{c}$ diagram is assumed in accordance with $\mathrm{Eq}(6)$ which has three parameters: $E_{c}, f_{c}^{\prime}$ and $\varepsilon_{0}$. Most of references [8-15] suggest $\varepsilon_{0}$ values within the interval $0.0020-0.0022$ for concrete of average strengths. It is shown later that $\varepsilon_{0}$ does not significantly influence the computed $\sigma_{t}-\varepsilon_{t}$ curve when a constant value of $E_{c}$ is assumed. Therefore, a reasonable value for $\varepsilon_{0}$ can be predefined. Since $E_{c}$ and $f_{c}^{\prime}$ are related by Eq $6(\mathrm{~b})$, only one parameter is needed to fully define the $\sigma_{c}-\varepsilon_{c}$ relation. It will also be shown that the accurate value of $E_{c}$ in combination with a not accurate $f_{c}^{\prime}$ still gives a reasonably correct $\sigma_{t}-\varepsilon_{t}$ relation and curvature, but that an accurate value for $f_{c}^{\prime}$ in combination with an inaccurate value for $E_{c}$ gives misleading results.

When this technique is used to compute both $\sigma_{c}-\varepsilon_{c}$ and $\sigma_{t}-\varepsilon_{t}$ relations, two experimental moment-strain, (or curvature) diagrams are needed. It is to be expected that different combinations of moment- 
strain relations can be used, but the present research employed moment-steel strain $(M-\kappa)$ and momentcurvature $(M-\kappa)$ relations. Computation is performed iteratively according to the following steps:

1) A free but reasonable value for the concrete modulus of elasticity $\bar{E}_{c}$ is assumed. For $\varepsilon_{0}$ taken from the interval $\varepsilon_{0}=0.0020-0.0022, f_{c}^{\prime}$ is computed from Eq. (6b) and the initially assumed compressive concrete $\bar{\sigma}_{c}-\bar{\varepsilon}_{c}$ relation is defined by (6a);

2) The $\sigma_{t}-\varepsilon_{t}$ curve is computed from the $M-\kappa$ diagram;

3) Using the computed $\sigma_{t}-\varepsilon_{t}$ curve, the relation $\tilde{\sigma}_{c}-\widetilde{\varepsilon}_{c}$ is obtained from $M-\kappa$ diagram;

4) A new $E_{c}$ and the corresponding $\sigma_{c}-\varepsilon_{c}$ relation are assumed using values that give best agreement for $\sigma_{c}-\varepsilon_{c}$ with $\widetilde{\sigma}_{c}-\widetilde{\varepsilon}_{c}$.

5) If $E_{c} \cong \bar{E}_{c}$, computation of $\sigma_{c}-\varepsilon_{c}$ is considered to be finished. Otherwise another iteration is performed starting from step 2 .

6) After the $\sigma_{c}-\varepsilon_{c}$ relation is finally defined, the $\sigma_{t}-\varepsilon_{t}$ relation is obtained either from the $M-\kappa$ or from the $M-\varepsilon_{s}$ relation.

The procedures proposed are illustrated in the following by several numerical examples which reveal the sensitivity of the results to the parameters $E_{c}, f_{c}^{\prime}$, and $\varepsilon_{0}$. All data, except for values of $E_{c}, f_{c}^{\prime}$ and $\varepsilon_{0}$, are taken from the previous example (Figs 4 and 5). Three data sets with varying $E_{c}, f_{c}^{\prime}$ and $\varepsilon_{0}$ as shown in Table 1 are considered. For case 1 the input data are identical to those for the previous example (Figs 4 and 5). It is the ideal case since $M-\varepsilon_{s}$ and $M-\kappa$ curves were generated from its data. Case 2 with three different input data sets is a combination of case 1 and $E_{c}$ and $f_{c}^{\prime}$ values obtained for $\varepsilon_{0}$ of 0.0015 . The latter value can be considered a lower limit to $\varepsilon_{0}$ for average strength concrete. Case $2 \mathrm{a}$ uses the $E_{c}$ of case 1 with a decreased $f_{c}^{\prime}$ corresponding to $\varepsilon_{0}$ of 0.0015 . Case $2 \mathrm{~b}$ retains the initial $f_{c}^{\prime}$, but has an increased $E_{c}$ corresponding to that for the same $\varepsilon_{0}$ as case 2a. Case $2 \mathrm{c}$ has an initial $\varepsilon_{0}$ of 0.0021 , but takes decreased $f^{\prime}$ from case $2 \mathrm{a}$ and, therefore, has a decreased $E_{c}$ value. Case 3 is designed similarly to case 2 with the difference that $E_{c}$ and $f_{c}^{\prime}$ values are based on a reasonable upper limit for $\varepsilon_{0}$ assumed to be 0.0027 .
Table 1. Assumed material parameters for compressive concrete

\begin{tabular}{|c|c|c|c|}
\hline Case & $E_{c} \times\left(10^{-4}\right)[\mathrm{MPa}]$ & $f_{c}^{\prime}[\mathrm{MPa}]$ & $\varepsilon_{0}$ \\
\hline 1 & 3.95 & 41.25 & 0.0021 \\
\hline 2a & 3.95 & 29.63 & 0.0015 \\
b & 5.50 & 41.25 & 0.0015 \\
c & 2.82 & 29.63 & 0.0021 \\
\hline 3a & 3.95 & 53.33 & 0.0027 \\
b & 3.06 & 41.25 & 0.0027 \\
c & 5.08 & 53.33 & 0.0021 \\
\hline
\end{tabular}

The computed $\sigma_{t}-\varepsilon_{t}$ curves for cases 2 and 3 are presented in Figs 7 and 8 respectively. The correct curve corresponding to case 1 is shown by a circled line. It is apparent that good accuracy has been achieved for cases 2a and 3a having the correct value of $E_{c}$ combined with poor values for $f_{c}^{\prime}$ and $\varepsilon_{0}$. Cases $2 b$ and $3 \mathrm{~b}$ having the correct value for $f_{c}^{\prime}$ and cases $2 \mathrm{c}$ and $3 \mathrm{c}$ having the correct value for $\varepsilon_{0}$ produced inaccurate $\sigma_{t}-\varepsilon_{t}$ curves.

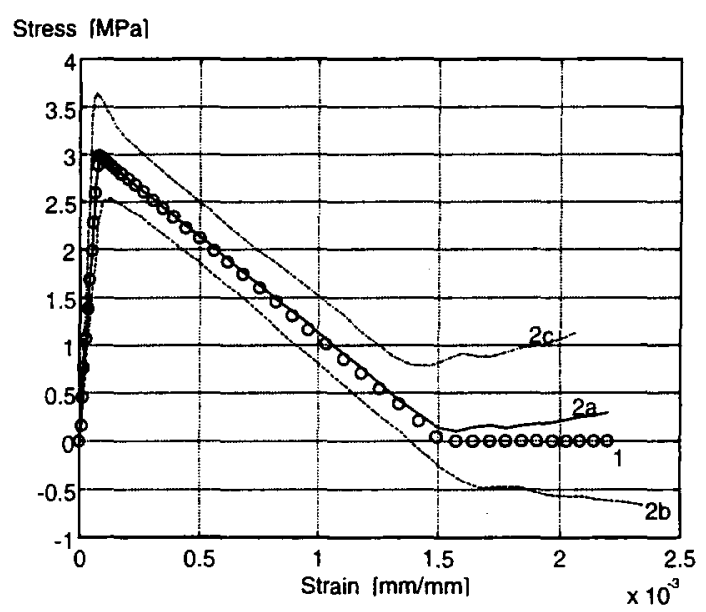

Fig 7. Computed $\sigma_{t}-\varepsilon_{t}$ curves for case 2

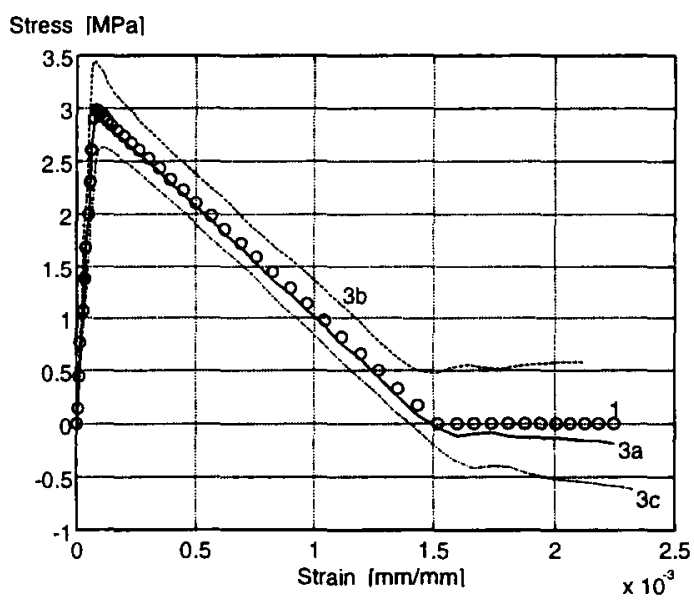

Fig 8. Computed $\sigma_{t}-\varepsilon_{t}$ curves for case 3 
Good agreement for the $\sigma_{t}-\varepsilon_{t}$ curves of cases 1 , 2a, and $3 \mathrm{a}$ having a constant value for $E_{c}$ can be explained by the similarity of the assumed $\sigma_{c}-\varepsilon_{c}$ relations (Fig 9), at stages where tension stiffening effects are present.

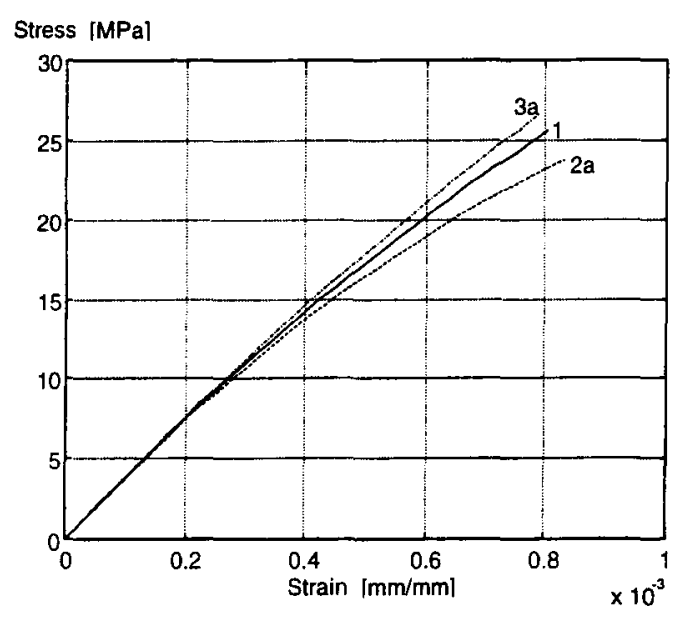

Fig 9. Assumed $\sigma_{c}-\varepsilon_{c}$ curves for cases $1,2 \mathrm{a}$ and $3 \mathrm{a}$

Since for correctly assumed values of $E_{c}$, good accuracy is achieved even for the limiting values $\varepsilon_{0}$ of 0.0015 and $0.0027, \varepsilon_{0}$ can be eliminated as unknown and an average value within the interval 0.0020-0.0022 assumed. With $E_{c}$ and $\varepsilon_{0}$ known, the compressive strength $f_{c}^{\prime}$ can be obtained from Eq (6b).

The technique proposed here allows the computation of not only the $\sigma_{t}-\varepsilon_{t}$ relation, but also the $\sigma_{c}-\varepsilon_{c}$. relation. No information on concrete material properties are needed in order to obtain these diagrams. However, it must be noted that $f_{c}^{\prime}$ determined this way is not necessarily accurate since this technique is primarily for defining the $\sigma_{t}-\varepsilon_{t}$ relation. A further research based on the method proposed should be carried out in order to investigate fully the $\sigma_{c}-\varepsilon_{c}$ relation. Results of such research could then be applied to tension stiffening problems.

An example, (Figs 4 and 5), extensively used in this paper is employed once again to illustrate how, in the iterative process, the correct $E_{c}$ and approximate $f_{c}^{\prime}$ values can be determined. As it was noted previously, each iteration includes two computations: 1) the $\sigma_{t}-\varepsilon_{t}$ curve is computed from the experimental $M-\varepsilon_{s}$ relation; and 2) using the resulting $\sigma_{t}-\varepsilon_{t}$ curve, the $\sigma_{c}-\varepsilon_{c}$. relation is defined from $M-\kappa$ diagram. The strain $\varepsilon_{0}$ was assumed to be 0.0020 , but not
0.0021 which is the correct value. An initial value for $E_{c}$ equal to $1.925 \times 10^{4} \mathrm{MPa}(50 \%$ of the correct value) was assumed deliberately as a low value. Results of the computation are presented in Fig 10 and

a)

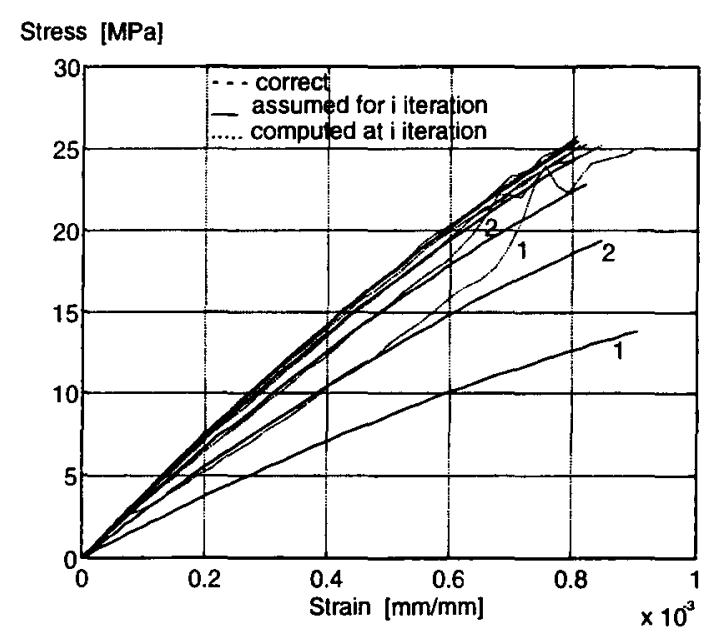

b)

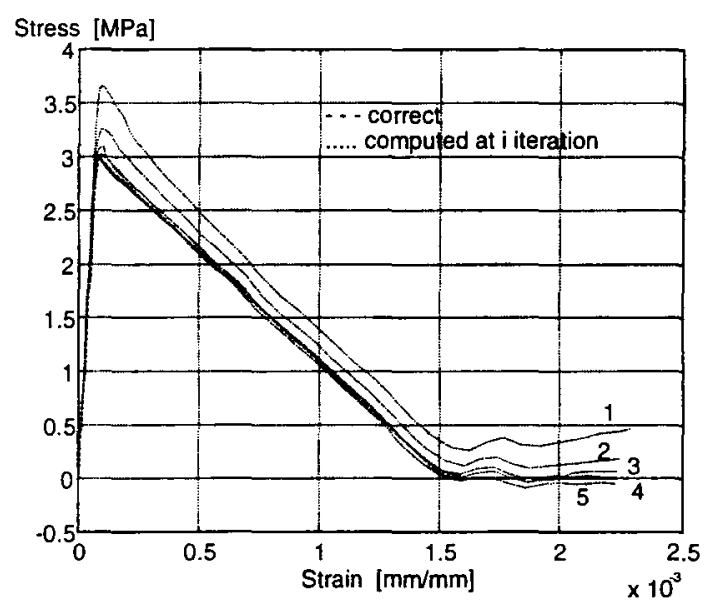

Fig 10. Iterative computation of stress-strain relationships (a) - for compressive concrete; (b) - for tensile concrete. $1,2,3,4$ and 5 - iteration number

Table 2. Dashed lines in Fig 10 indicate the correct $\sigma-\varepsilon$ relationships both for tensile and compressive concrete which are expected to be approached in the iterative process. The computed $\sigma-\varepsilon$ relationship corresponding to iteration $i$ is shown by a dotted curve. The assumed $\sigma_{c}-\varepsilon_{c}$ relationship corresponding to iteration $i$ is shown by a solid line in Fig 10(a). It can be seen from Fig 10(b) that three iterations were needed to get $\sigma_{t}-\varepsilon_{t}$ relationship which is very close to the correct one. The correct $\sigma_{c}-\varepsilon_{c}$ curve was reasonably approached in four iterations (Fig 10(a)). Alt- 
hough the correct $E_{c}$ value was obtained after five iterations (Table 2), the corresponding $f_{c}^{\prime}$ value was not very accurate having the same degree of error as the assumed $\varepsilon_{0}$ value.

Table 2. Assumed $E_{c}$ and $f_{c}^{\prime}$ values in the iterative process

\begin{tabular}{|c|c|l|}
\hline Iteration No & $E_{c} \times\left(10^{-4}\right)[\mathrm{MPa}]$ & $f_{c}^{\prime}[\mathrm{MPa}]$ \\
\hline 1 & 1.975 & 19.75 \\
2 & 2.95 & 29.5 \\
3 & 3.5 & 35.0 \\
4 & 3.8 & 38.0 \\
5 & 3.95 & 39.5 \\
\hline
\end{tabular}

\section{Conclusions}

Further developments on a recently proposed method [1-5] for determining average stress-strain relations for concrete from flexural tests of reinforced concrete members are presented. Based on the method, two practical techniques assessing scatter of the experimental data have been proposed. By the first technique, an average stress-strain relation for concrete in tension is determined from one experimental moment average strain (or curvature) diagram when the stressstrain relation for concrete in compression is assumed to be known. By the second technique, in an iterative way using two experimental moment-average strain (curvature) diagrams average stress-strain relations for concrete in tension as well as in compression are defined. In this case, just the shape of the parabolic stressstrain relationship for concrete in compression is assumed and its parameters such as modulus of elasticity and (cylinder) strength of concrete are determined by computation.

At present the proposed practical techniques are applied to actual experimental data. This will be the subject of subsequent publications.

\section{Acknowledgments}

The work was carried out in the Department of Civil Engineering of the University of Illinois, UrbanaChampaign, USA. Professors J. Ghaboussi and N. Hawkins are gratefully thanked for their critical support and advice throughout the research. The financial support provided by the University of Illinois and US Information Agency under Fulbright grant is gratefully acknowledged.

\section{References}

1. G. Kaklauskas. A Method for Determination of StressStrain Relations for Concrete from Experimemental Data of RC Bending Members// Statyba. N 2(10). Vilnius: Technika, 1997, p. 60-68.

2. G. Kaklauskas. A Method for Investigation of Tension Stiffening Effect of Flexural RC Members // Proceedings, Conf. Building and Architecture, Kaunas, Lithuania, April 9-11, 1997, p . 157-164.

3. G. Kaklauskas, J. Ghaboussi, and N. M. Hawkins. Determination of Stress-Strain-Curves for Concrete from RC Beam Tests // Proceedings, Fifth Int. Conf Modern Building Materials and Techniques, Vilnius, Lithuania, May 21-24, 1997. V.: Technika, 1997, p. 138-145

4. G. Kaklauskas. A Technique for Investigation of Tension Stiffening Effect of Flexural RC Members // Proceedings, 10th Nordic Seminar on Computational Mechanics, Tallin, Estonia, October 24-25, 1997, p. 228 231.

5. G. Kaklauskas, J. Ghaboussi, and X. Wu. Neural Network Modelling of Tension Stiffening Effect for R/C Flexural Members // Proceedings, EURO-C 1998Computational Modelling of Concrete Structures, Badgastein, Austria, March 31 - April 3, 1998 ( to be published).

6. The Student Edition of Matlab: Version 4. The MathWorks Inc. Prentice Hall, Englewood Cliffs, 1995.

7. V. Jokūbaitis. Dèsningu ir atsitiktiniu plyšiu ittaka armuoty betoniniy sijy deformacijoms, veikiant trumpalaikei apkrovai: Disertacija technikos moksly kandidato laipsniui igyti / Kauno politechnikos institutas, 1967. $235 \mathrm{p}$

8. Eurocode No 2, Design of Concrete Structures, October 1991.

9. C. E. B.-FIP Model Code $1990 / /$ Bulletin d'Information No. 203, Chap. 2, July 1991

10. T. Szulczynski and M. A. Sozen. Load-Deformation Characteristics of Reinforced Concrete Prisms with Rectilinear Transverse Reinforcement // Structural Research Series No. 224, Civil Engineering Studies (University of Illinois, Urbana, IL, September 1961).

11. H. E. Roy and M. A. Sozen. A Model to Simulate the Response of Concrete to Multi-Axial Loading // Structural Research Series, No. 268, Civil Engineering Studies (University of Illinois, Urbana, IL, June 1963).

12. A. C. Liebenberg. A Stress Strain Function for Concrete Subjected to Short-Term Loading // Mag. Concr. Res. 14 , No.41, 1962, p. 85-99.

13. D. C. Kent and R. Park. Flexural Members with Confined Concrete // Proc. ASCE, No 97, 1971, p. 1969 1990.

14. S. Popovics. A Numerical Approach to the Complete Stress-Strain Curves for Concrete // Cement Concr. Res, No 3, 1973, p. 583-599. 
15. L. E. Young. Simplifying Ultimate Flexural Theory by Maximizing the Stress Block // ACI J., 57, No 5, 1960 , p. 549-556.

\section{Iteikta 19980111}

\section{PRAKTINĖS METODIKOS BETONO VIDUTINIU ITEMPIU-DEFORMACIJU DIAGRAMOMS NUSTA- TYTI IŠ LENKIAMU GELŽBETONINIU ELEMENTU EKSPERIMENTINIU DUOMENU}

\section{G. Kaklauskas}

\section{S a n t r a u k a}

Straipsnyje aprašomi nauji pasiekimai, plètojant neseniai pasiūlytą metodą [1-5], kuriuo iš lenkiamų gelžbetoninių siju eksperimentinių duomenų gali būti nustatytos betono vidutiniu itempių-deformaciju diagramos. Turint eksperimentines momentų-kreivių ir momentų-deformacijų diagramas, gaunama pilna tempiamo betono vidutiniu itempiųdeformaciju diagrama, iskaitant ir jos krentančiają dali. Taip pat, net neturint duomenų apie betono savybes, pakankamai tiksliai galima rasti ir gniuždomo betono diagramą. Skaičiavimas pagristas nauja ideja, kai tempiamo ir gniuždomo betono vidutinių ịtempių-deformacijų diagramos skaičiuojamos kraštiniams lenkiamo elemento sluoksniams. Turint eksperimentines kraštinių sluoksnių deformacijas, kiekvienai apkrovos pakopai nustatomi tụ sluoksnių itempių prieaugiai. Kiekvienoje apkrovos pakopoje gautos diagramos taikomos kitiems mažiau deformuotiems sluoksniams. Pasiūlytasis metodas patikrintas skaitiškai.
Remiantis Šiuo metodu, pasiūlytos dvi inžinerinès skaičiavimo metodikos, ivertinančios eksperimentinių duomenu išsibarstyma. Pirmaja metodika, turint vieną eksperimentinę momentu-vidutinių deformacijų (kreivių) diagramą nustatoma tempiamo betono vidutinių jtempių-deformaciju kreive. Šiuo atveju gniuždomo betono ittempių-deformaciju kreive yra laikoma žinoma. Antraja metodika, turint dvi eksperimentines momentų-vidutinių deformacijų (kreiviu) diagramas, iteraciniu būdu nustatomos tiek tempiamo, tiek gniuždomo betono vidutinių ịtempių-deformacijų kreivès. Pastaruoju atveju laikoma, kad betono diagrama yra žinomos parabolès formos, o ją apibrežiantys dydžiai - betono tamprumo modulis ir prizminis (arba cilindrinis) stipris nustatomi skaičiavimu.

Gintaris KAKLAUSKAS. Doctor, Senior Researcher and Associate Professor. Dept of Reinforced Concrete Structures, Vilnius Gediminas Technical University, Sauletekio al. 11, 2040 Vilnius, Lithuania.

A graduate of Vilnius Civil Engineering Institute (presently Vilnius Gediminas Technical University), 1982 (civil engineer). $\mathrm{PhD}, 1990$. Research visits: Aalborg University (Denmark), 1991; University of Glamorgan (UK), 1994/1995; University of Illinois, Urbana-Champaign (USA), 1996. Author and co-author of 2 monographs, 1 invention and a number of papers. Research interests: development of average stress-strain relationships for concrete in tension and numerical simulation of reinforced concrete flexural structures. 